\title{
The Budget rule: reducing oil dependence
}

\author{
Andrey Brodunov ${ }^{1, *}$, Natalia Bushueva ${ }^{1}$, Alexander Averin ${ }^{2}$, and Ekaterina Berezina ${ }^{3}$ \\ ${ }^{1}$ Moscow University named after S.Yu. Witte, 2nd Kozhukhovsky passage, 12, bld.1, 115432, \\ Moscow, Russia \\ ${ }^{2}$ Financial University under the Government of the Russian Federation, Leningradsky Prospekt, 49, \\ 125993, Moscow, Russia \\ ${ }^{3}$ Vyatka State University, Moskovskaya str., 36, 610000, Kirov, Russia
}

\begin{abstract}
The article explores a way to reduce the dependence of the national currency on oil prices. A retrospective analysis of the data showed a close correlation between the ruble, the US dollar and the price of oil in the international market. Since 2004, a budget rule has been in effect in Russia, imposing a long-term restriction on budget policy through quantitative restrictions on budget indicators. The study analyzes the limitations of the budget rule in the Russian Federation in various periods and its results. The authors conducted a comparative analysis of foreign experience in reducing dependence on petrodollars on the basis of five reserve funds. The study demonstrates that the budget rule could be one of the possible measures to reduce the dependence of the national currency on oil prices.
\end{abstract}

\section{Introduction}

The problem of the national currency stability is always relevant and it is a complex socioeconomic issue the state faces. As is well known, the stability of the national currency depends on the fundamental factors of the economy, which are the basis of investment decisions and they are closely related to financial risks, which include a currency risk. The study of these factors helps to establish the relationship of exchange rates with certain events and to carry out budget planning at the state level, considering possible changes.

The history of the dependence of the Russian economy on the oil price begins in the 1960s. It is related to the signing of the resolution of the USSR Council of Ministers 'About the price change and the replacement of the present money correlation by new money' in May 1960 [1]. As it turns out, this 'replacement' had great plans and caused negative results. The research is an attempt to figure out how this decision affected the establishment of a close link between the rate of the ruble and the oil price.

Before the reform in early 1961 the US dollar cost was 4 rubles or 0.4 rubles according to the new calculation. However, after the reform, the dollar exchange rate was set at 0.9 rubles. At first glance, the ruble had become more expensive but in fact, the dollar had risen significantly - from 40 cents to 90 cents (in the new calculation), that is - just 2.25 times. As

\footnotetext{
${ }^{*}$ Corresponding author: abrodunov@muiv.ru
} 
a result, the ruble was underestimated by 2.25 times, and the purchasing power of the ruble to imported goods decreased by the same time.

Why, then, did they need that reform? The answer to this question in the fact that there was a jump of oil production in the USSR in the post-war period, the leap was from 20 to 148 million tons per year. The graph below illustrates this (Fig. 1) [2].

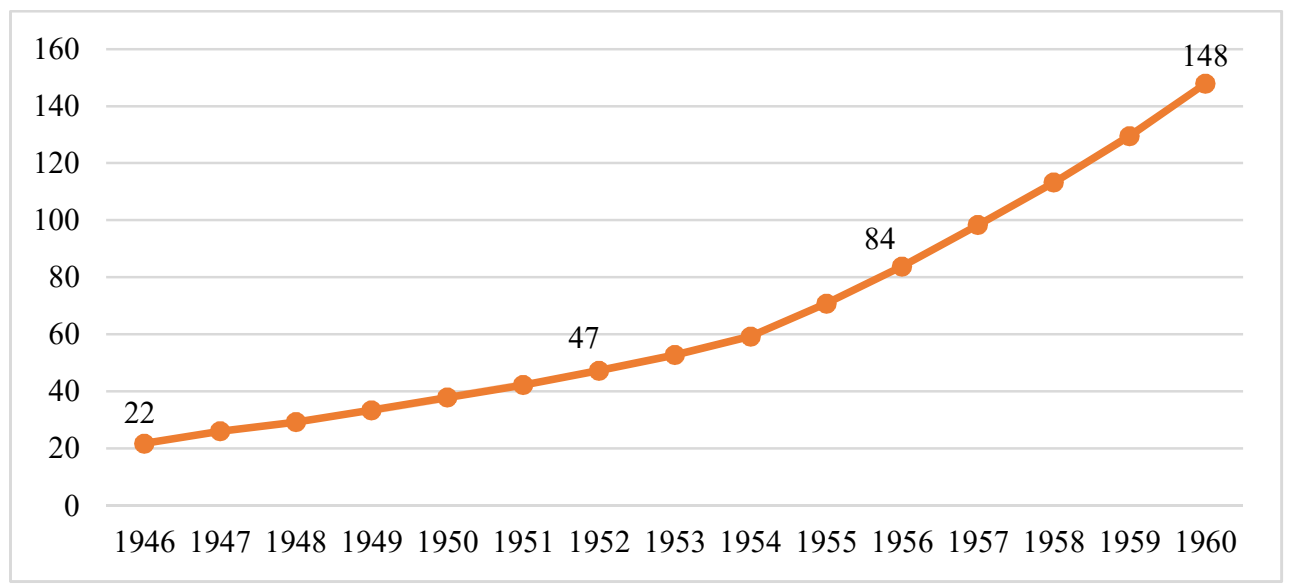

Fig. 1. Oil production in the USSR (million tons).

Then, in May 1960, it was decided to start a large-scale export of crude oil to the foreign market. The export of crude oil and petroleum products from the Soviet Union in the first post-war years was insignificant and amounted to less than $4 \%$ of the exchange earnings from the entire foreign trade balance of the country. The reason for this situation was mainly in the fact that in the 1950s the cost of a barrel of crude oil was less than USD $\$ 3$ or 12 soviet rubles on the world market, and the cost price of production and transportation of crude oil from the USSR was less than 9.5 rubles. The profitability of crude oil supplies to foreign markets was meagre, this hindered the increase in its supply [3].

Thus, in the sixties of the last century with a sharp increase in oil production by 7.5 times, for a sharp increase in crude oil exports to global markets was required a change in the ratio of the ruble to the US dollar. A serious impetus to increase the volume of crude oil supplies abroad was also the 'emaciated' country budget as a result of all the innovative reforms in the agricultural and industrial economic areas. The monetary reform leads to the increase of a crude oil price up to 27 soviet rubles per barrel, and thus the oil export (while maintaining its value on world markets and production costs) became very profitable. In that way, the currency reform of the 1961 was not a denomination, but a far-reaching policy of binding the country's economy to the petrodollar.

According to some economists, this political decision had caused irreparable damage to the country's economy for many years.

The change in world oil prices is one of the many factors that affect the Russian economy. An oil price reduction hurts a payment balance, reducing the value of exports, as well as on the economy of the country in general. Usually a prices reduction adversely affects the dynamics of a stock market. While reducing oil prices, inflationary pressure affects the ruble exchange rate, causing an increase in the money supply and the emergence of monetary inflation. It, to some extent, has an impact on the increase in the competitiveness of domestic producers, because imports, for obvious reasons, are getting more expensive. Moreover, since the oil price is expressed in US dollars, the correlation between the oil quotes and the US dollar rate is evident. 
To reduce the negative consequences of the oil price volatility for the Russian economy, the monetary authorities of the country adopted 'budget rule'. In this case, the budget rule is a financial rule that imposes a long-term restriction on fiscal policy through quantitative restrictions on budget indicators.

The budget rule is the only mechanism that has proven itself in the international experience. It helps to reduce the dependence of the federal budget and the domestic economic conditions on energy prices for commodity-dependent countries through sterilizing oil and gas excess profit of the budget and accumulation of sovereign funds.

\section{Methods and materials}

In order to identify and understand the problems of stability of the national currency, it is necessary to study its dependence on various external factors. In the Russian Federation, a fundamental factor is the change in world oil prices.

The study requires a retrospective analysis of the formation of the dependence of oil prices and the US dollar. For this, statistics on changes are used:

- ruble exchange rate;

- US dollar rate;

- the cost of oil in the international market.

Statistical materials for the study were taken in open sources and were subjected to a correlation analysis procedure to identify the relationship of values and the cause-effect relationship between them. The study does not fall under the limitations of correlation analysis, since there are enough observations to study, the data are qualitatively uniformed and multidimensionally normally distributed.

An independent factor in the retrospective analysis was the 'budget rule'. An analysis of its qualitative composition may indicate the effectiveness of introducing certain quantitative restrictions on budget policy.

The study of international experience also gives an understanding of the effectiveness of certain actions in the framework of state financial policy regulation. The study used materials from the Norwegian Petroleum (Pension) Fund (Statens pensjonsfond utland, SPU) [4], the Alaska Permanent Fund [5], the Kuwait Future Generations Fund [6], the Saudi Arabia Sovereign Fund (SAMA Foreign Holdings) [7] and the State Reserve Fund of Oman [8].

\section{Results}

The economic crisis of 1998-1999 strongly affected the ruble exchange rate (Fig. 2) [9]. The Russian Central Bank also played a vital role in this with the policy of hard containment of the ruble. The consequences of the crisis effected in the economy until 2004. 


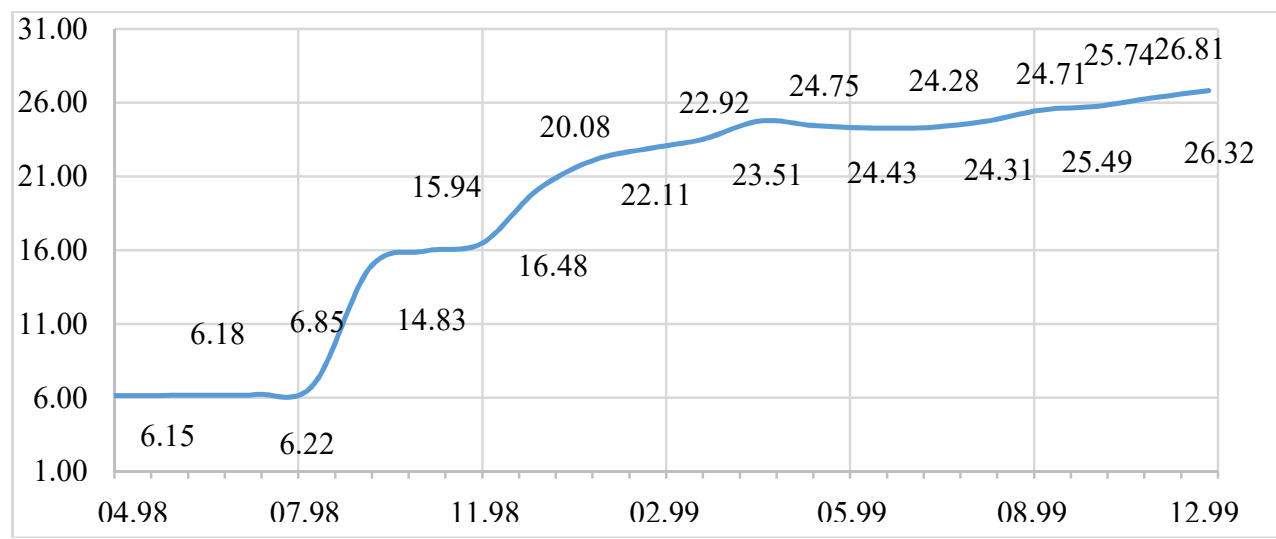

Fig. 2. The US dollar exchange rate against the ruble 1998-1999.

In 2004 the Russian Ministry of Finance has introduced amendments to the Budget Code of the Russian Federation, where appeared the concept of 'cut-off price' of revenues from petrodollars. The received excess profit was sent to the Stabilization Fund. The cut-off price was initially set at $20 \mathrm{USD} / \mathrm{bbl}$, and since 2006 at $27 \mathrm{USD} / \mathrm{bbl}$.

Since 02 February 2008, the Stabilization Fund has been divided into two parts:

- The Reserve Fund;

- The National Wealth Fund.

In the crisis of 2008, the cut-off price was set at 45-50 USD/bbl.

However, in 2007, amendments to the Budget rule were adopted: oil and gas revenues could be directed by the government to cover the budget deficit, but only in a particular ratio to GDP. For example, the government proposed to allow to spend in 2008 oil dollars in the amount of $6.1 \%$ of GDP, followed by a decrease - in $20095.5 \%$, in $20104.5 \%$, in $20113.7 \%$, and so on.

Nevertheless, because of the economic crisis, this Budget rule was not applied until 2012.

In 2012 at the international economic forum in St. Petersburg, the Russian President formulated some changes to the Budget rule. The point of the suggested changes are as follows: at high world oil prices, the state accumulates excess profit in the funds, and at low oil prices - uses the available savings for the realization of current liabilities. The logic of these amendments is to ensure the possible risks of fulfilment of the state obligations, budget and investment programs from fluctuations in the price of oil on the world market.

The distribution of excess profit of petrodollars was proposed to be carried out as follows.

The portion of the excess profit received in a rise in oil prices above projection will be deposited into the Reserve Fund, and when it reaches the level of the Fund to the required amount to $7 \%$ of GDP, the funds received $(50 \%)$ shall be transferred to infrastructure and other priority projects. The remaining excess profit must be credited to the National Wealth Fund. If the world oil prices fall below the planned ones, then the funds from the Reserve Fund are used to repay the budget deficit, but they should not exceed 1\% of GDP.

In November 2014, the ruble became a freely floating currency. Until that time, the ruble exchange rate to other foreign currencies was established and regulated by the Central Bank of the Russian Federation and since that time - the value of the ruble is not set but determined by sales on the currency exchange. Thus, the ruble being mostly a "commodity" of free circulation. It is subordinated in its pricing to the balance of supply and demand: the more buyers for the Russian ruble, the more expensive it is, and vice versa - the more actively the ruble is sold, the cheaper it is. 
It is essential to note that the dependence of the ruble to the cost of a barrel of oil on world markets is not the only one factor. Buying and selling the ruble on foreign currency exchanges are characterized by many factors such as the state of the economy, the presence of various sanctions, an attractive investment policy, and just bad or good news.

Besides, the ruble mostly affects domestic prices: the weaker the ruble, the higher inflation. But not only the ruble affects domestic prices, but it also affects the prices of exporters - the lower the ruble, the lower their prices in the world market. At the same time, this ruble exchange rate reduces imports - the price of goods translated into the national currency increases. Therefore, the floating exchange rate of the ruble works as a "built-in stabilizer" of the economy, which allows smoothing the impact of external stimuli such as the fall in oil prices, the next sanctions and others.

The work of this mechanism is seen when comparing two recent economic crises- the crisis of 2008 and the crisis of 2014. In the crisis of 2008, the ruble was regulated by the Central Bank, and it trying to save the ruble from the collapse, actively sold the currency on the stock exchange. A sharp fall in the rate did not happen then, but the country paid for it with a sharp drop in the industry and GDP, as well as a jump in unemployment.

Comparing the last crisis of 2014 with the previous one, though it was better from the economic point of view, it can be concluded that the floating ruble exchange rate helped to smooth its consequences.

For comparison, the several indicators can be sited: in 2009, industrial production in our country decreased by about $11 \%$, and in 2015 this figure was only $3.4 \%$, primarily due to the floating exchange rate of the ruble.

However, what is the real cost of the ruble? How is the ruble exchange tied to the cost of a barrel of oil? Let us try to explain it.

Having the statistical data on the cost of a barrel of oil and the current exchange rate of the ruble, numerical series and using regression analysis can be obtained and a pattern in the form of a formula can be shaped. This helps to identify the dependence of one value on the other.

Different indicators of the price of a barrel of crude Brent oil* with the corresponding courses of the ruble from the archive of the Central Bank of the Russian Federation were compared [10]. The results of the analysis are presented in the following table (Table 1).

Table 1. The average cost of a barrel of oil*.

\begin{tabular}{|c|c|c|c|}
\hline Date 2018 & USD/bbl & The average rate of the ruble & Oil price, rubles \\
\hline January & 68.89 & 56.79 & 3912.26 \\
\hline February & 64.65 & 56.81 & 3672.77 \\
\hline March & 69.34 & 57.03 & 3954.46 \\
\hline April & 74.62 & 60.46 & 4511.53 \\
\hline May & 77.56 & 62.21 & 4825.01 \\
\hline June & 79.23 & 62.71 & 4968.51 \\
\hline July & 74.2 & 62.88 & 4665.70 \\
\hline August & 77.71 & 66.12 & 5138.19 \\
\hline September & 82.73 & 67.69 & 5599.99 \\
\hline October & 74.61 & 65.89 & 4916.05 \\
\hline November & 59.25 & 66.25 & 3925.31 \\
\hline December & 53.80 & 67.33 & 3622.35 \\
\hline The average & 71.38 & 62.68 & 4476.01 \\
\hline
\end{tabular}

* Used the data for Brent crude oil.

Thus, the average cost of a barrel of oil at the level of 4504 rubles was obtained, with the maximum deviation in the smaller direction $-24.34 \%$, in the broader direction - 
$19.57 \%$. Because the measurement itself was carried out according to the schedule and has some error, authors can safely conclude the waiting for the average monthly price of a barrel of oil at the level of 4500 rubles with a possible dispersion of results in $5 \%$. It should be clarified that this is a relatively simplified model of calculation.

The linking of the ruble to the dollar is laid by the government at the stage of budget formation. The government should receive as much revenue in rubles from the sale of oil as they plan to spend. Consequently, the ruble is based on the planned government expenditure. In other words, all produced and sold barrels of oil for the year (at the constant price in rubles), in advance counted and divided before selling. Based on such calculations, various scenarios for the Russian economy shortly are predicted. In this case, both negative and positive scenarios are calculated.

However, it is possible to derive the 'ideal ruble exchange rate' only in the case when it is possible to determine the year in which the ruble exchange rate was 'fair'. Thus, moving on the schedule of the ruble to different years, equally suitable indicators for comparison can be observed. But, at the same time, they are equally incorrect.

Therefore, authors conclude that the ruble depends on many different parameters: on the dollar or preferably on the basket of currencies (the dollar itself fluctuates relative to the currency basket), on the real volumes of exports and imports, on the real actions of the Central Bank of Russia, on investment policy and many other factors.

The figure 3 indicates the percentage deviation of the market values assessment for different multi-parameter models, based on the regression for data 2000-2004. All values of variables (except Interest) are logarithmic [11].

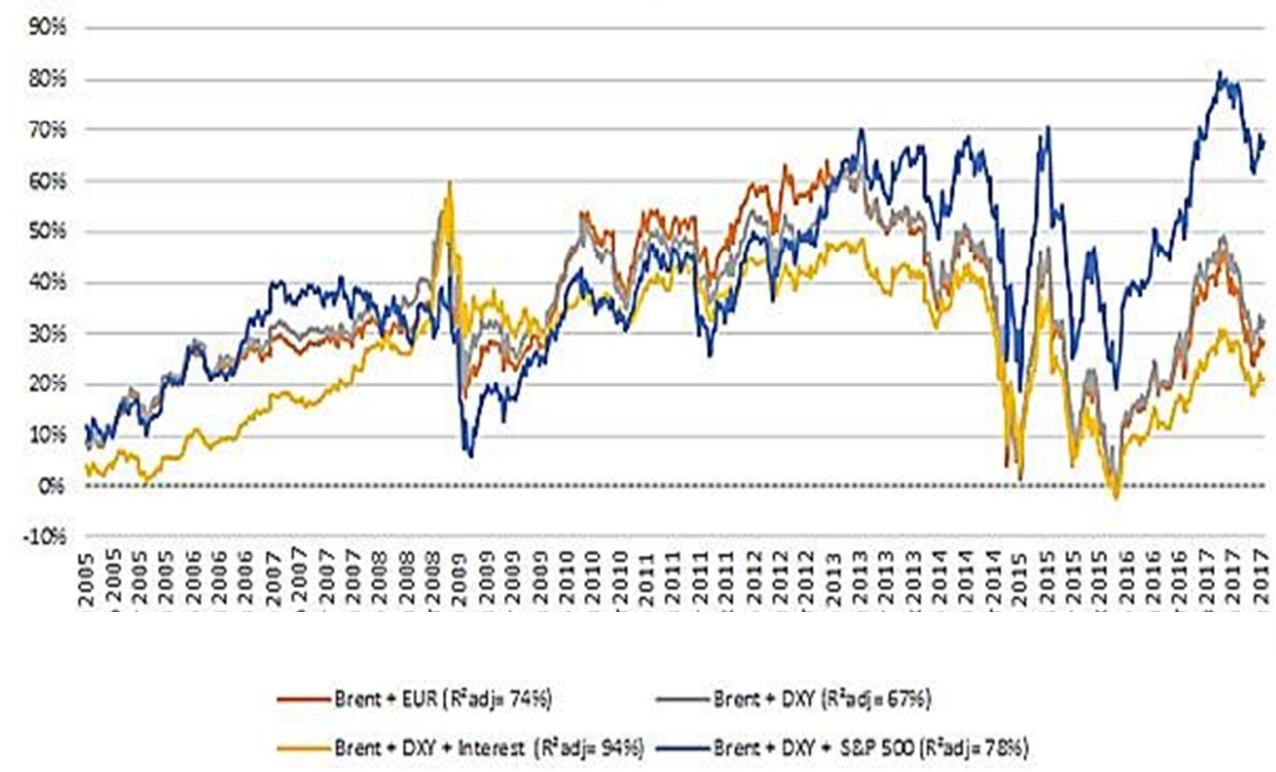

Fig. 3. The percentage deviation of the market values assessment for different multi-parameter models.

Paradoxically, the use of a single parameter model (the Brent oil price) helps to obtain consistently reliable results that surpass other models in the accuracy of the fair exchange rate assessment of the ruble in the forecast periods (Fig.4-5). Moreover, this model, based on the 2000-2004 data, provides an acceptable accuracy of the ruble exchange rate up to the present day. 
Thus, authors conclude that the 'fair' exchange rate of the ruble today can be estimated with sufficient accuracy, using only two main factors: the ratio of inflation in our country and the United States and the cost of a barrel of Brent oil.

However, the budget rule described earlier soon has changed. At the end of 2017, the Ministry of Finance presented a new version of the Budget rule. It is provided to list all additional income from the oil revenues in the Reserve Fund, and the cut-off price provided for in $50 \mathrm{USD} / \mathrm{bbl}$. The idea behind this formulation of the New Budget rule was to prevent the strengthening of the ruble and the negative impact of changes in oil prices on the prospects for economic growth, inflation, and interest rates.

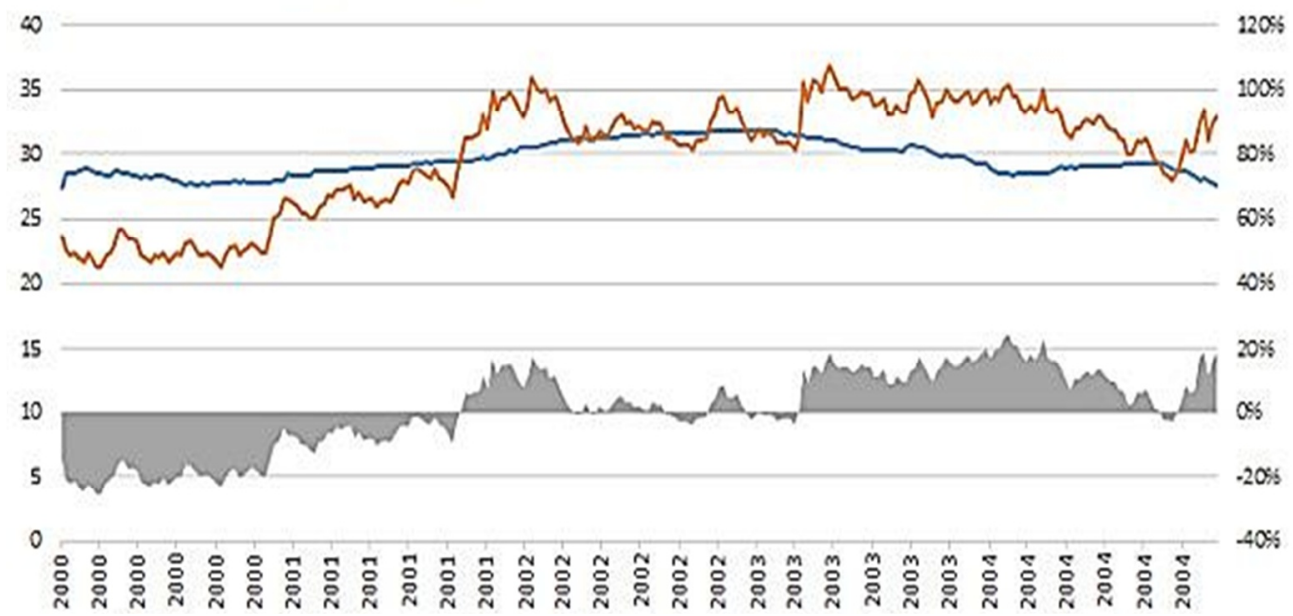

Fig. 4. Estimation of the ruble exchange rate and its market value for a model with a single explanatory variable (Brent oil price) in a data sample 2000-2004.

According to some economists [12], the Ministry of Finance fears that the increase in world oil prices will lead to the strengthening of the ruble and the government will be tempted to increase the current budget spending sharply. Therefore, the new budget rule provides for all additional petrodollars to accumulate in the Reserve Fund; it means that excess profits will not be able to enter the domestic market and put pressure on the money supply and the ruble.

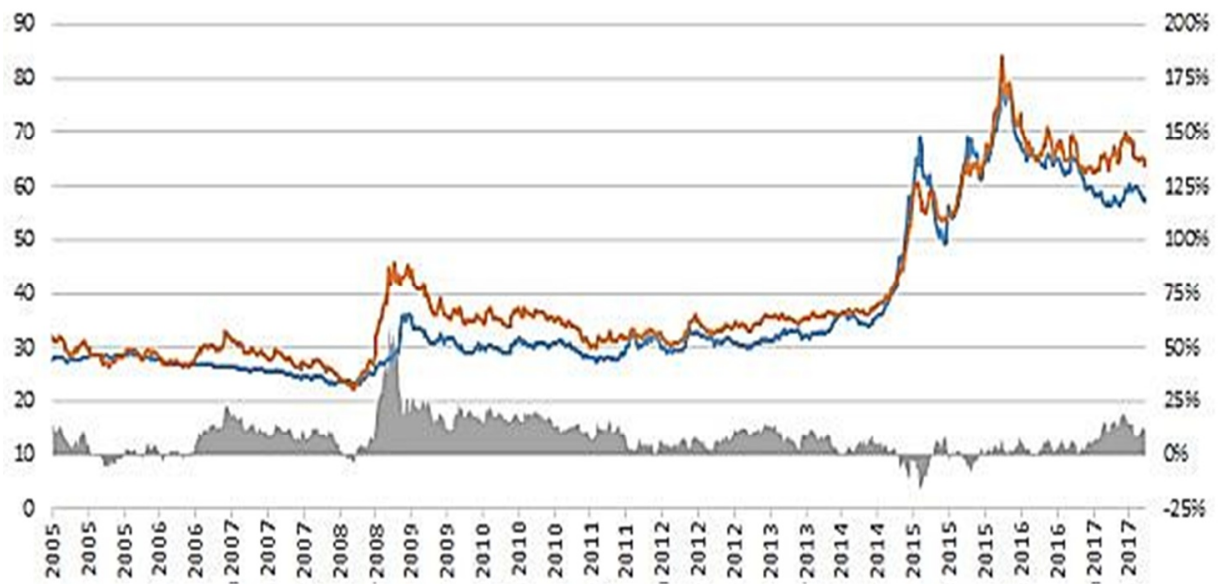


Fig. 5. Estimation of the ruble exchange rate and its market value for a model with a single explanatory variable (Brent oil price) based on a regression using the data sample 2000-2004.

The change in the reserves of the Russian Federation is shown in Figure 6 [13-14].

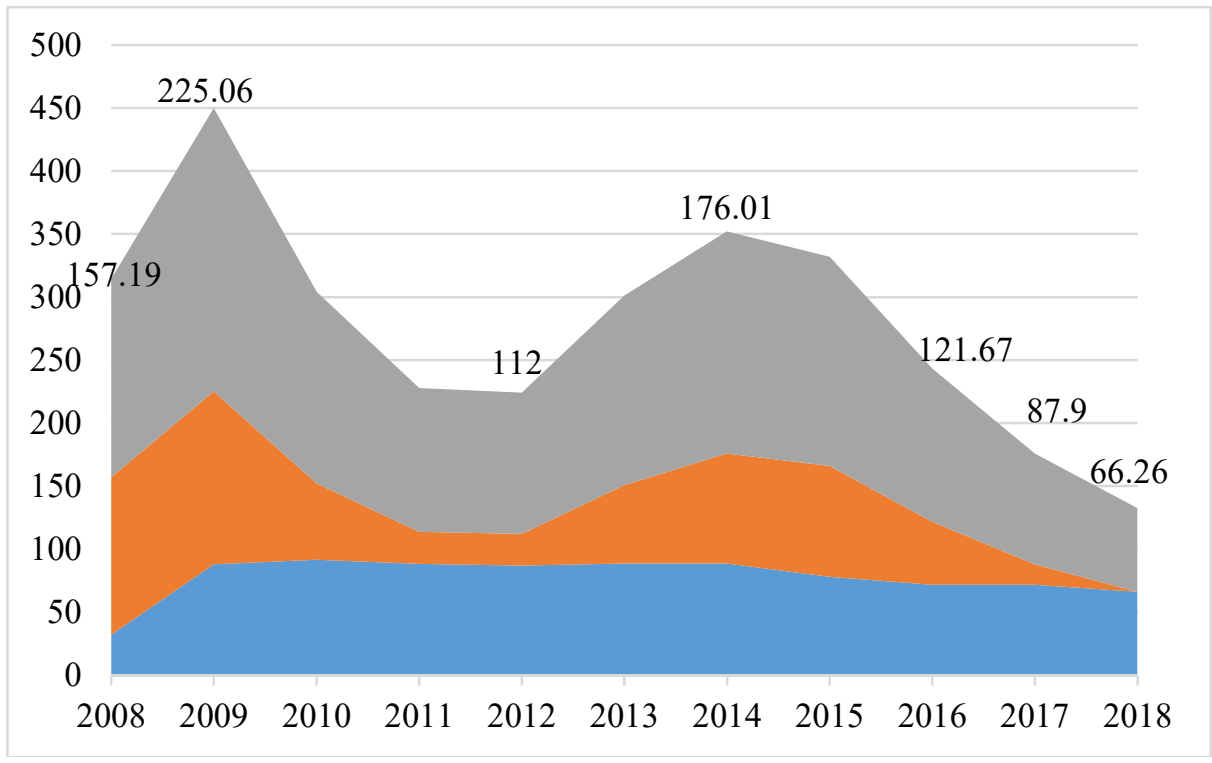

Fig. 6. The dynamics of Russia's reserves 2008-2018.

\section{Discussion}

Analyzing the main differences between the New budget rule and its previous version, authors note that in the previous Budget rule the cut-off price was calculated as the average price per barrel of Brent crude oil for the previous few years. In the New budget rule, the cut-off price is set as the fixed price $50 \mathrm{USD} / \mathrm{bbl}$. This price is chosen as the most probable 'structural' price per barrel of oil in the long term (for 10 - 15 years).

The new budget rule also prescribes a mechanism for the purchase of currency for excess profits from petrodollars. In this case, the agent of the Ministry of Finance for the purchase of currency on the market is the Central Bank, and the Ministry of Finance buys currency directly from the Central Bank.

It is believed that the new budget rule will significantly reduce the sensitivity of macroeconomic indicators and the ruble to oil prices on the world market. It is aimed at stabilizing not the budget, but the economy of the country. The combination of the old budget rule and the existing taxation of the oil sector of the economy led to increased sensitivity of macroeconomic indicators and the ruble exchange rate to world oil prices. The new budget rule should correct the situation, leaving the progressive taxation in the oil and gas industry and smoothing the dependence of the ruble exchange rate with the growth or fall in oil prices.

However, not all analysts share the rosy optimism of our government financiers. Thus, experts of the Analytical credit rating Agency (ACRA), accredited to the Central Bank, in October, 2018 presented a pessimistic scenario of the macroeconomic forecast for 2019, in which, in the case of tightening of sanctions (as it is predicted) the dollar average for the year might be 83 rubles, and GDP at the end of the year may fall by $2.5 \%$ [15]. ACRA specialists presented 3 scenarios: Basic (B), Alternative (A), Alternative + Stress $(A+S)$ where expected tightening sanctions in November 2018 and tightening trade wars. 
According to the ' $\mathrm{A}+\mathrm{S}$ ' scenario, the critical rate of the Central Bank will increase from $7.5 \%$ to $12 \%$, while inflation will increase from the expected $4 \%$ to $8 \%$ in 2019 . At the same time, the risks of sanctions expansion and trade wars are for the first time laid in the development of the basic scenario of the macroeconomic forecast. Analysts from ACRE believe that the dollar at the peak of its volatility may be above 83 rubles, but the Central Bank will stop this growth of the dollar through an increase in the critical rate. Such a scenario is possible in the event of budget crises in some European countries, the debt crisis in China and the recession in the United States.

In the development of ' $A$ ' scenario, analysts also predicted the possible shocks from excessive oil supply in the world markets, which can lead to a drop-in oil price to 40 USD/bbl and below for 1-1.5 years. Another significant risk is the possible onset of a recession in the United States, which is predicted by an increasing number of leading economists. The fall of GDP in Russia in 2019 was provoked by the Central Bank itself. Such a conservative forecast of the Central Bank was based on the following factors: in case of expansion of sanctions, acceleration of capital outflow and deterioration of the situation in the economies of developing countries, and even a drop-in oil prices below 35 $\mathrm{USD} / \mathrm{bbl}$.

In the 'B' scenario, ACRA analysts forecast GDP growth of $1.4 \%$ in 2019 , and the dollar exchange rate is 64 rubles, the projected inflation is $4.6 \%$, the critical rate remains unchanged and is $7.5 \%$. However, at the same time, according to analysts, the ' $\mathrm{B}$ ' scenario is becoming less and less likely, although it is not thrown out of forecasts. All this can be explained as by external factors as by uncertainty in both the domestic budget policy and the monetary policy.

However, the 'budget rule' is not the prerogative of the Russian Federation and is used in hydrocarbon exporting countries.

For example, the Norwegian oil (pension) Fund (Statens pensjonsfond utland, SPU) was established in Norway in 1990 [4]. It was created as the Reserve Stabilization Fund for future generations. The Norwegian government decided to invest a part of the profits from oil production (which at that time was a quarter of the country's income) in profitable foreign companies, developing business, bonds. To date, the Stabilization Fund owns various shares of about 10 thousand different companies around the world, which is more than $2 \%$ of the shares of the entire European stock market and at least $1 \%$ of the shares of the world market. So today the Fund owns shares of Nestle, Alphabet, Microsoft and Apple, it also owns government bonds of the United States, Germany and Japan. By September 2016, the Fund's investment income had reached 7.3 trillion NOK or about 882 billion USD, double the country's GDP, making Norway's reserve Fund the largest Fund in the world. Now the government and politicians of the country face a difficult task not to waste a considerable amount of savings, not to pamper the population and not to act morality. The government did not spend the money from the Stabilization Fund until the beginning of 2016 when funds were needed to exclude a recession in the country due to a sharp drop in world oil prices. The main features of the Reserve Fund of Norway are the fact that the government of the country is transparent and thrift in the management of the Fund. Any citizen can follow the incoming revenue from investments online. At the same time, despite the considerable amount of accumulated money, budget rules prescribe the government of the country to spend no more than $4 \%$ of the established annual income from it, leaving the fixed capital of the Fund untouched.

A vital fast, in this case, is the trust of the population, which is currently at a high level now, as the Fund's expenses are based on the principles of social equality and cultural homogeneity of the population.

One more feature in the use of the Reserve Fund in Norway, strangely enough, is the question of the ethics of investment. A lot of politicians and public people of the country 
are trying to convince the society that the ethical aspect of the investment issue is much more essential for a democratic state than obtaining a purely financial profit. Therefore, based on its moral principles, the money of the Reserve Fund is never invested in companies that produce 'questionable products': tobacco products, weapons, products that harm the environment, and others.

In 1976, the American state of Alaska created the Permanent Fund, which accumulates funds of excess profits from the sale of oil [5]. This Fund transfers $25 \%$ of the funds received by the state government from oil companies in the form of taxes, purchase of drilling licenses, payment for the operation of oil pipelines, and others. A part of the incoming petrodollars from the oil companies of Alaska go directly to the residents of the region. For example, in 2014, each resident of the region received 1884 USD. The investment portfolio of the Permanent Fund includes shares of various US companies, US bonds, securities of other countries, real estate and other assets. In 2016, the amount of the Permanent Fund exceeded 53 billion USD.

Kuwait is one of the largest oil suppliers in the world market. It created the Budget Reserve Fund and the Reserve Fund for the future generations in 1960-1970 [6]. The Reserve Fund of the future generations receives $10 \%$ of the state revenues regardless of their origin and current oil prices. The accumulated funds are invested in various companies in developed countries. The accumulated funds in the accounts of the funds helped to restore the state after the first Gulf war in 1990-1991.

Surprisingly, the world's largest oil producer and supplier are Saudi Arabia, whose 9095\% treasury consists of energy exports for a long time did not have its separate reserve fund. However, the global decline in oil prices on the world market has forced the ruling family to change their view of the excess revenues from energy sources. So, in April 2016, the kingdom, preparing for the 'twilight of the oil age', created the Sovereign Fund [7] of 2 trillion USD to get rid of oil dependence in the future.

In 1980, the State Reserve Fund was established in Oman [8]. In 1993, the second Fund was created, the Oil Fund. However, the activities of these funds in Oman were ineffective. It was not possible to fill these funds with money due to the constant borrowing from funds to cover the budget deficit in the country.

\section{Conclusion}

The problem of national currency stability has deep historical roots, the solution of which is a complex socio-economic problem. For the internal stabilization of the ruble, it is essential to make efforts to strengthen the confidence of the national currency not less than the dollar. The confidence in national currency, along with the measures already applied by the authorities, could affect the change in the market situation, in consequence of the growth of the economy and the standard of living of the population.

The foreign experience demonstrates the tremendous efforts of countries to eliminate the dependence of the country's welfare on petrodollars. To do this, the state economic policy should find a balance between the vector of development associated with the accumulation in sovereign funds, and investments to the development of real sectors.

\section{References}

1. E. Spitsyn, How the ruble was tied to the oil (2016) https://www.liveinternet.ru/users/guboss/post384260195/

2. The national economy of the USSR, http://istmat.info/node/388 
3. Information and analytical resource 'PetroDigest'. Barrel of oil, https://petrodigest.ru/articles/neft/barrel-nefti

4. The Norwegian Petroleum (Pension) Fund, https://www.nbim.no/

5. Alaska Permanent Fund, https://apfc.org/

6. Kuwait Future Generations Fund, https://kia.gov.kw/investments/

7. Saudi Arabia Sovereign Fund (SAMA Foreign Holdings), http://www.sama.gov.sa/enUS/Pages/default.aspx

8. State Reserve Fund of Oman, https://www.sgrf.gov.om

9. The history of the US dollar currency exchange rate, https://www.calc.ru/kotirovkadollar-ssha.html

10. The central Bank of the Russian Federation. Dynamics of the official rate of a given currency, http://www.cbr.ru/currency_base/dynamics/?UniDbQuery.Posted=True\&Uni DbQuery. mode $=1 \&$ UniDbQuery.date_req $1=\& U$ UniDbQuery.date_req $2=\& U$ UniDb Query.VAL_NM_RQ=R01235\&UniDbQuery.FromDate $=01.12 .2018 \& \overline{\text { UniDbQuery.T }}$ o

11. E. Kireu, A. Movchan, The formula of the ruble. How to calculate the exchange rate of the Russian currency at any time (CARNEGIE Moscow Center, 2017) https://carnegie.ru/commentary/73225

12. E. Metelitsa, O. Volkova, Ya. Milyukova, I. Tkachev, RBK 065(2321) (2016) https://www.rbc.ru/newspaper/2016/04/13/570cf2919a7947d3fd3d9044

13. Ministry of Finance. The amount of the Reserve Fund, https://www.minfin.ru/ru/document/?id_4=27067

14. Ministry of Finance. The amount of the National Welfare Fund, https://www.minfin.ru/ru/document/?id_4=27068

15. Analytical credit rating Agency (ACRA), https://www.acra-ratings.ru/research 